\title{
A Review on the Electrochemical Applications of Room Temperature Ionic Liquids in Nuclear Fuel Cycle
}

\author{
K.A. Venkatesan, T.G. Srinivasan,* and P.R. Vasudeva Rao \\ Chemistry Group, Indira Gandhi Centre for Atomic Research, Kalpakkam 603 102, India
}

Received: September 16, 2008

A mini review on the electrochemical applications of room temperature ionic liquids (RTIL) in nuclear fuel cycle is presented. It is shown that how the fascinating properties of RTIL can be tuned to deliver desirable application in aqueous and non-aqueous reprocessing and in nuclear waste management.

\section{Introduction}

Reprocessing of spent nuclear fuels. Nuclear reactors employ natural or enriched uranium as the fuel. Reprocessing of spent nuclear fuel is adopted for closing the nuclear fuel cycle and this practice maximizes the full potential of fissile elements, uranium and plutonium, and enhances resource utilization. ${ }^{1}$ The technology for reprocessing of spent nuclear fuel has been in vogue for several decades. The irradiated nuclear fuel is conventionally reprocessed by industrially well-established PUREX process, ${ }^{2}$ which employs tri- $n$-butyl phosphate (TBP) as extractant and $n$-dodecane ( $n$-DD) or a mixture of aliphatic straight chain hydrocarbons $\left(\mathrm{C}_{12}-\mathrm{C}_{14}\right)$ as diluent. Uranium(VI) and plutonium(IV) are extracted using $1.1 \mathrm{M}$ $\mathrm{TBP} / n$-DD from $3.0 \mathrm{M}-4.0 \mathrm{M}$ nitric acid medium and the fission products are rejected to the "high-level liquid waste" (HLLW). The uranium and plutonium are then stripped from organic phase into dilute nitric acid and converted to their respective oxides for feeding back into the reactor. In contrast to the aqueous based PUREX process, reprocessing is also performed by non-aqueous pyrochemical method. ${ }^{3}$ This process involves the dissolution of spent nuclear fuel in molten chloride salt medium followed by selective electrodeposition of actinides. $^{3,4}$ Traditionally, the electrolytic medium is composed of a eutectic of alkali or alkaline earth chlorides, molten at temperatures above $800 \mathrm{~K}$ depending upon the composition of the chosen eutectic.

Room temperature ionic liquids. Room temperature ionic liquids (RTILs) are receiving an upsurge, in recent years, for possible application in various stages of nuclear fuel cycle. RTILs $^{5-7}$ are compounds composed only of ions and molten at temperatures lower than $373 \mathrm{~K}$. They are generally made up of a bulky, unsymmetrical organic cation and an organic or inorganic anion. Some examples of cation and anion combinations for making RTIL are shown in Figure 1. RTILs have several fascinating properties unique to a combination of particular cation and anion. ${ }^{7}$ The properties such as insignificant vapor pressure, amazing ability to dissolve organic and inorganic compounds and wide electrochemical window are the specific advantages when dealing with applications for nuclear fuel cycle. The ionic liquids are regarded as designer or tailormade solvents as their properties can be tuned for desired application. An excellent review by Wilkes ${ }^{8}$ describes about the historical perspectives of room temperature ionic liquids, pioneers in that area, events and the products delivered till 2001. Furthermore, several comprehensive reviews on room

*Corresponding author. E-mail: tgs@igcar.gov.in, Fax: $+91-44-27480065$ temperature ionic liquids by various authors are described elsewhere. ${ }^{9-14}$

Historical development of RTIL - in brief. It is interesting to note that the birth of RTIL ${ }^{15}$ started with electrochemistry, when Walden synthesized and studied the electrochemical application of ethylammonium nitrate, known as room temperature molten salt in 1914. The first generation RTILs are based on chloroaluminate anions emerged ${ }^{16}$ in the middle of $20^{\text {th }}$ century, when Hurley and Wier employed chloroaluminate bath for electroplating aluminium in the year 1948. However the properties and their applications of chloroaluminates were not studied in detail until Osteryoung and Wilkes ${ }^{17}$ rediscovered the potentials of chloroaluminate melts and delivered several elec-

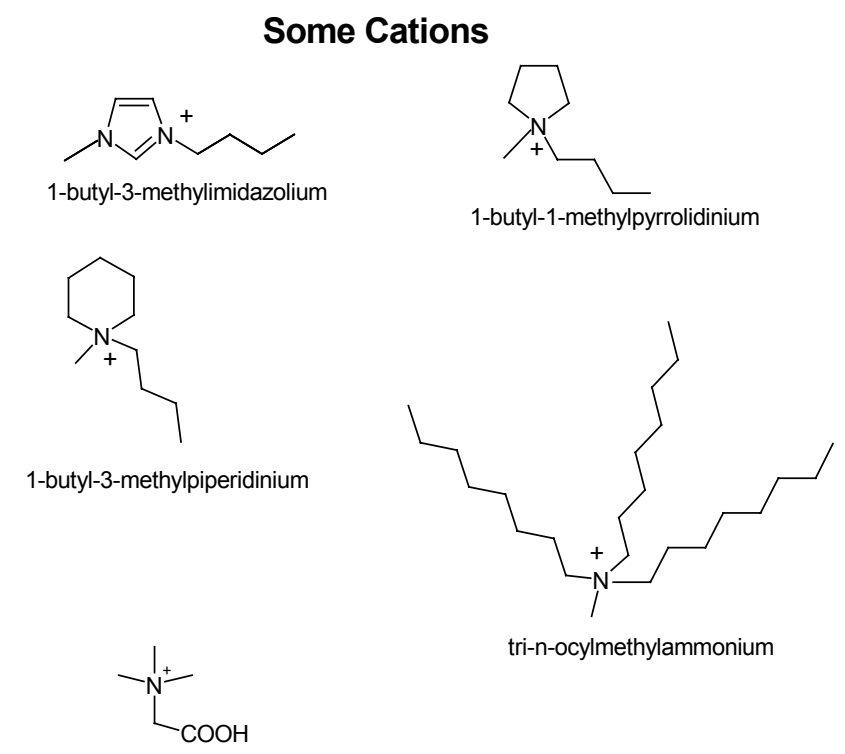

carboxy-N,N,N-trimethylmethanaminium

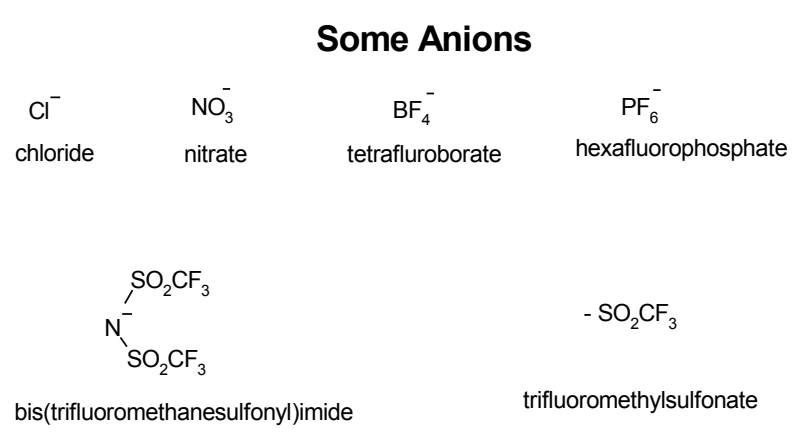

Figure 1. Examples of some cations and anions for making RTIL. 
trochemical applications in late 1970s. At the same time, it was also realized that these haloaluminate based ionic liquids had a limited scope as they were moisture sensitive and required a non-ambient conditions for their synthesis and applications. Substantial advancement in this area of research emerged with the discovery moisture-stable ionic liquids in 1992 by Wilkes and co-workers. ${ }^{18}$ These RTILs have nonhydrolyzing or stable anions, such as $\mathrm{PF}_{6}^{-}, \mathrm{BF}_{4}^{-}, \mathrm{NO}_{3}^{-}$, $\mathrm{CH}_{3} \mathrm{COO}^{-}$etc, in place of haloaluminate anion. These are known as $2^{\text {nd }}$ generation RTILs. This discovery unfolded the inherent potentials and promises of RTILs. The subject, room temperature molten salt confined only to electrochemists before 1990, took a new dimension in the form of room temperature ionic liquid and opened new avenues for research in all branches of science, especially in organic synthesis, catalysis, electrochemistry, and separation science.

Scope. Literature survey on RTILs indicates that there is an exponential growth of articles and reviews since the discovery of moisture stable second-generation RTILs. ${ }^{14}$ The survey is also applicable to the electrochemistry of RTILs ${ }^{10-14}$ that essentially dealt with both fundamental aspects such as transport, heterogeneous electron transfer, double layer capacitance, redox behaviour of inorganic compounds etc., and applied studies such as electrochemical activator, photo electrochemical cells, super capacitors, and batteries etc. However, the reports on the application of RTIL to nuclear industry were not as huge as other applications. The evolution of electrochemical applications of RTILs to nuclear industry started in the beginning of this century, and in the last few years the applications are significant. Moreover, an exclusive review on this subject is still missing. Therefore the primary aim of the present review is to draw the attention of researchers/electrochemists and expose the potentials of RTILs for nuclear applications. This was attempted primarily with the data generated in our laboratory apart from other data focusing on nuclear applications. This review, thus, provides an overview of the electrochemical applications of RTILs in spent fuel reprocessing and nuclear waste management. To facilitate the reader in this regard, the review has been divided into the applications pertaining to aqueous reprocessing, non-aqueous reprocessing and other electrochemical applications in nuclear industry. It also provides a future scope of RTILs for nuclear application and major issues that are to be addressed in this area.

\section{Aqueous reprocessing}

The PUREX process ${ }^{2}$ flow sheet for the separation and recovery of uranium and plutonium from spent nuclear fuel solution is illustrated in Figure 2. The heart of the separation process involves the solvent extraction of uranium (VI) and plutonium (IV) from nitric acid medium by $1.1 \mathrm{M}$ TBP/n-DD as discussed earlier. It is important to recognize that, in all the solvent extraction systems reported to date, the extractants are traditionally diluted with molecular diluents, such as $n$-dodecane in PUREX process. However, the employment of RTIL as an alternative to $n$-dodecane in solvent extraction process was introduced by Dietz ${ }^{19}$ and Rogers. ${ }^{20}$ The properties of RTILs such as insignificant vapour pressure, miscibility with various extractants, and tunability of properties through the change in the combination of cation and anion are the specific advantages when dealing radioactive solutions. The study revealed the unusual and favorable extraction behavior when RTILs are used in conjunction with extractants. ${ }^{21-26}$ Moreover, with the availability of wide electrochemical window and good conductivity, unique for RTIL diluents, it is possible to envisage a new mode of recovery of metals by direct electrodeposition from organic phase. ${ }^{27,28}$ This variation indeed avoids the traditional stripping step, which generates large volumes of aqueous waste. It also eliminates the re-conversion procedures that involve

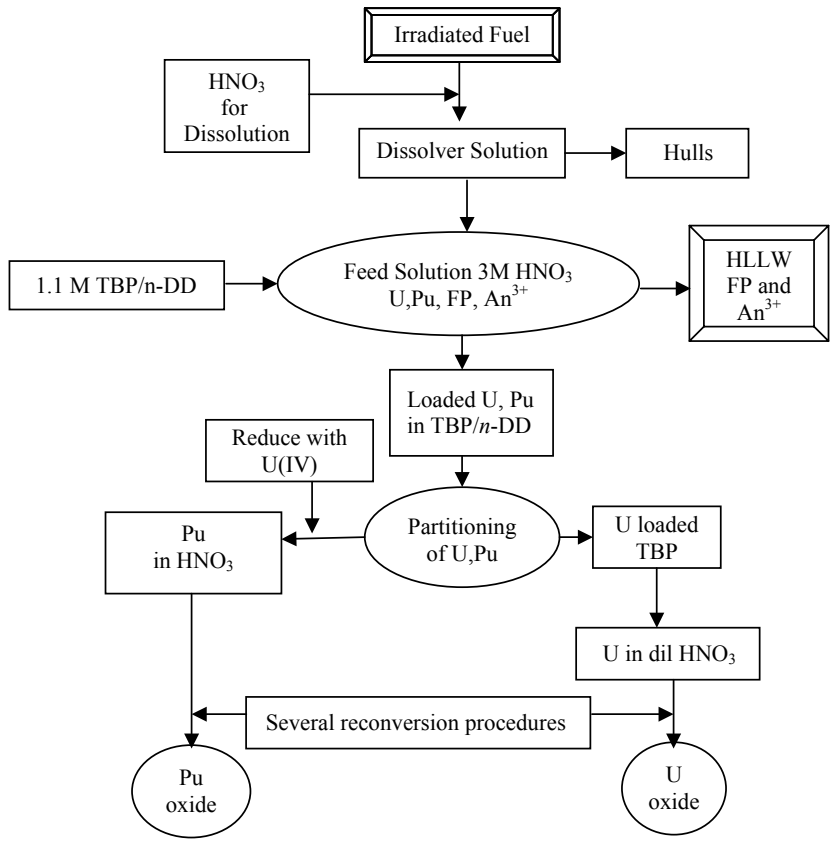

Figure 2. PUREX process flow-sheet.

chemical transformation of the metal ion present in the aqueous strip in to a suitable form (metallic or oxide). In this direction, the first paper on the extraction of radiotoxic fission products ${ }^{137} \mathrm{Cs}^{+}$by Calix[4] arene-bis(tetraoctylbenzo - crown 6) (BOB-Calix-C6) and ${ }^{90} \mathrm{Sr}^{2+}$ by dicyclohexano-18-C6 (DCH18C6) present in tri-1-butylmethylammonium bis((trifluoromethyl)sulfonyl)imide ionic liquid followed by a simple electrochemical recovery was reported by Hussey and co-workers. ${ }^{27,28}$ The electrochemistry of $\mathrm{Cs}^{+}$and $\mathrm{Sr}^{2+}$ in the organic phase was studied by various electrochemical techniques at mercury film electrode. The study revealed that the fission products could be recovered by electrodeposition of loaded organic phase at mercury electrode with a coulometric efficiency of $\sim 90 \%$. Later $\mathrm{Chen}^{29}$ investigated a similar system in the presence of oxygen, moisture and counter ions, which are likely to be extracted in organic phase and may also interfere in the electrochemical recovery of fission products during electrodeposition. The replacement of nitrate ions in the extracted phase by halides and complete removal of dissolved oxygen and moisture by purging dry nitrogen into the extracted organic phase are recommended before electrochemical recovery of fission products.

The first paper on the extraction of actinide, uranium (VI), from nitric acid medium followed by electrodepositon from organic phase was reported by Giridhar et al. ${ }^{30}$ Commercially available long chain quaternary ammonium chloride, aliquat336 (tri- $n$-octylmethylammonium chloride, TOMAC) was employed as extractant in the study. Previously, in the year 1965 Koch $^{31}$ studied the extraction of uranium (VI) from nitric acid medium by nitrate form of aliquat -336 (i.e. TOMAN) as extractant, and since these quaternary ammonium salts have desirable chemical and radiation stability, Koch recommended it for use in reprocessing of short-cooled high burn-up fuels. However, the extracted uranium was stripped with dilute nitric acid. In contrast, Giridhar et $\mathrm{al}^{30}$ studied the electrochemical method for the direct recovery of uranium from loaded organic phase. The study indicated that uranium (VI) in $0.05 \mathrm{M}$ TOMAC/CHCl ${ }_{3}$ underwent a single step two-electron transfer to uranium oxide at the working electrode with the current efficiency of $60 \%$. Similar to the work of Chen, ${ }^{29}$ the organic phase required a scrubbing with sodium nitrate solution, prior to electrolysis, to remove the extracted nitric acid.

Furthermore, the implications of using different RTILs for 
the solvent extraction of uranium (VI) were reported by Giridhar et al. ${ }^{32,33}$ Extraction behavior of U(VI) by a solution of 1.1 M TBP in 1-butyl-3-methylimidazolium hexafluorophosphate $\left(\right.$ bmimPF $\left._{6}\right)$ or bmimNTf ${ }_{2}\left(\mathrm{NTf}_{2}=\right.$ bis (trifluoromethanesulfonyl)imide) and the distribution ratios were compared with those obtained in traditional PUREX solvent $1.1 \mathrm{M} \mathrm{TBP} / n$-DD. In addition, the electrochemical stability of $1.1 \mathrm{M}$ solution of TBP/RTIL was investigated ${ }^{32}$ at glassy carbon working electrode and the voltammetric studies on uranyl nitrate extracted 1.1 M TBP/RTIL phase demonstrated the possibility of recovering uranium (VI) as uranium oxide deposit at the working electrode.

The above results suggest the interesting feasibility of using RTIL diluents for the recovery of metals. The target metal was extracted by a suitable ligand present in RTIL medium by solvent extraction procedure and recovered by electrodeposition. This process, called as Extraction-Electrodeposition (Ex-El Process) illustrated in Figure 3, was viable due to the characteristic property of RTIL that can perform both as diluent for the extractant and electrolytic medium for deposition of target metals.

\section{Non-aqueous reprocessing}

The concept of using RTILs for non-aqueous reprocessing has evolved recently. The electrochemistry of actinides and other metals in room temperature chloroaluminate melts $\left(1^{\text {st }}\right.$ generation RTILs) were indeed reported few decades ago. ${ }^{34}$ However, they were not directed towards electrodeposition of actinides, but involved only the basic understanding of complexation nature, solution chemistry and electrochemical behaviour of metals. In fact, this was due to the inadequacy in the electrochemical window and poor cathodic stability of $1^{\text {st }}$ generation chloroaluminates. Nevertheless, it is worthwhile to discuss those studies in the present review as they form a fundamental to the concept of using $2^{\text {nd }}$ and future generation RTILs for non-aqueous reprocessing. In this regard, a couple of reviews dealing with coordination chemistry of actinides in ionic liquids by Rogers and co-workers ${ }^{35}$ and lanthanide and actinides in ionic liquid by Binnemans ${ }^{36}$ merit recognition. The former review highlights the use of RTILs in separations, solidstate chemistry, spectroscopy and electrochemistry of actinides, and the later exhaustive review deals with solvation, spectroscopy, electrochemistry, solvent extraction, treatment of spent nuclear fuel, lanthanide mediated organic reactions, etc.

The earliest work on the electrochemistry of uranium in acidic and basic chloroaluminate melt was reported by D'Olieslanger and co-workers. ${ }^{34,37}$ In acidic 2:1 melts $\left(\mathrm{AlCl}_{3}\right.$ : $N$-(n-butyl)pyridinium chloride), the reduction of U(IV) to U(III) on glassy carbon electrodes was reported to be irreversible. The formal standard potential of the U(IV)/U(III) redox couple as a function of the melt acidity was determined and $\mathrm{U}(\mathrm{III})$ was found to exist as free $\mathrm{U}^{3+}$ ion, while $\mathrm{U}(\mathrm{IV})$ as chlorocomplexes, $\mathrm{UCl}_{x}{ }^{(4-x)+}$ with $3 \geq x \geq 1$. The oxidation of $\mathrm{U}(\mathrm{IV})$ to $\mathrm{U}(\mathrm{V})$ at glassy carbon electrodes was irreversible and dependent on the melt acidity. Further oxidation of U(V) to U(VI) was not feasible due to anodic instability of the melt. In contrast to acidic melts, $\mathrm{U}(\mathrm{VI})$ in basic melts ${ }^{38}\left(\mathrm{AlCl}_{3}+N-(n\right.$ butylpyridinium chloride)), exists as chloro complexes $\mathrm{UO}_{2} \mathrm{Cl}_{4+x}{ }^{(2+x)}$, which undergo a single step irreversible two electron transfer to soluble $\mathrm{UCl}_{6}^{2-}$ as shown in equation 1 . The diffusion coefficient of $2.65 \times 10^{-7} \mathrm{~cm}^{2} / \mathrm{s}$ was determined in slightly basic melt (mole ratio $\mathrm{AlCl}_{3}: \mathrm{BupyCl}=0.82: 1$ ). U(III) was insoluble in basic melt $\left(\mathrm{AlCl}_{3}+\mathrm{BupyCl}\right)$ and precipitated as $\mathrm{UCl}_{3}$ in neutral melt.

$$
\begin{array}{r}
{\left[\mathrm{UO}_{2} \mathrm{Cl}_{(4+x)}\right]^{(2+x)-}+2 \mathrm{AlCl}_{4}^{-}+2 \mathrm{e}^{-}} \\
\mathrm{UCl}_{6}{ }^{2-}+2 \mathrm{AlOCl}_{2}^{-}+(2+x) \mathrm{Cl}^{-}
\end{array}
$$

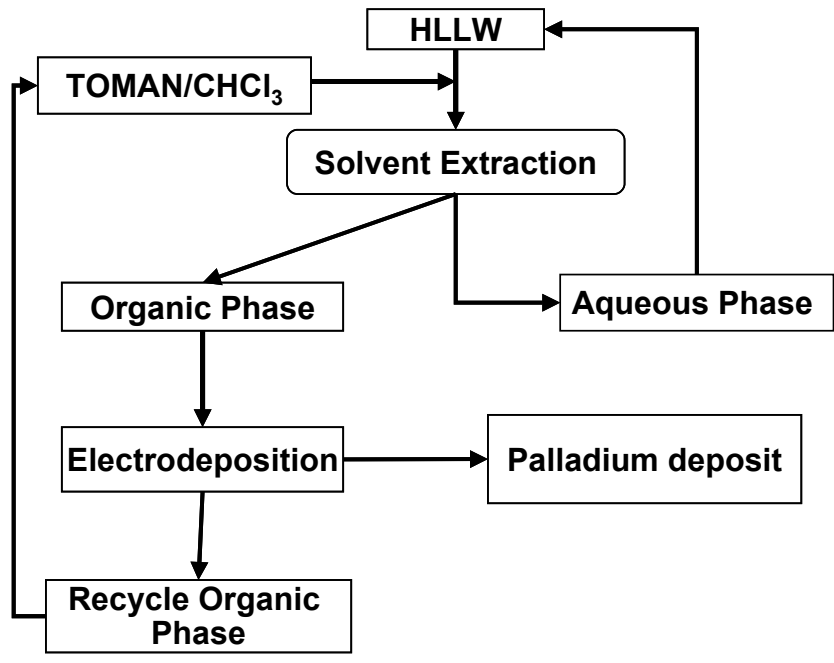

Figure 3. Extraction-Electrodeposition process for the recovery of palladium from HLLW. The process is feasible due to the characteristic property of RTIL, tri- $n$-octylmethylammonium nitrate (TOMAN), which act both as liquid ion exchanger during extractionand as electrolytic medium for the electrodeposition of palladium directly from loaded organic phase, with out invoking traditional stripping procedure with aqueous reagents.

In addition U(IV) could not be reduced to U(III) in basic melt due to the cathodic instability of Bupy ${ }^{+}$cation, which undergo reduction in preference of U(IV). However, U(VI) could be reduced to U(III) in basic $\mathrm{AlCl}_{3}$-1-ethyl-3-methylimidazolium chloride, ${ }^{39,40}$ as the 1-ethyl-3-methylimidazolium cation $\left(\mathrm{EMI}^{+}\right)$was more difficult to reduce than the Bupy ${ }^{+}$cation. The uranyl ion $\left(\mathrm{UO}_{2}{ }^{2+}\right)$ in basic $\mathrm{AlCl}_{3}-\mathrm{EMICl}$ melt undergoes a two electron transfer accompanied by the transfer of oxygen to chloroaluminate complex of ionic liquid leading to the formation of $\left[\mathrm{UCl}_{6}\right]^{2-}$ as shown in the following equations. $\left[\mathrm{UCl}_{6}\right]^{2-}$ was then reduced to $\left[\mathrm{UCl}_{6}\right]^{3-}$ in the melt.

$$
\begin{aligned}
& {\left[\mathrm{UO}_{2} \mathrm{Cl}_{4}\right]^{2-}+2 \mathrm{AlCl}_{4}^{-}+\underset{2\left\{\mathrm{AlOCl}_{2}\right\}^{-}+\left[\mathrm{UCl}_{6}\right]^{2-}+2 \mathrm{Cl}^{-}}{ }} \\
& {\left[\mathrm{UCl}_{6}\right]^{2-}+\mathrm{e}^{-} \rightleftharpoons\left[\mathrm{UCl}_{6}\right]^{3-}}
\end{aligned}
$$

Choppin and co-workers ${ }^{41}$ have investigated the electrochemistry and spectroscopy of $\mathrm{UO}_{2}{ }^{2+}$ in acidic $\mathrm{AlCl}_{3}-\mathrm{EMIC}$. $\mathrm{UO}_{2}{ }^{2+}$ in acidic $\mathrm{AlCl}_{3}-\mathrm{EMIC}$ melt was gradually reduced to $\mathrm{U}(\mathrm{V})$ and it was facilitated only by $\mathrm{AlCl}_{4}^{-}$and $\mathrm{Al}_{2} \mathrm{Cl}_{7}^{-}$species by the sequence of reactions shown in the following equations (4) to (6).

$$
\begin{aligned}
& \mathrm{UO}_{2}^{2+}+\mathrm{Al}_{2} \mathrm{Cl}_{7}^{-} \rightleftharpoons \mathrm{UO}^{4+}+\mathrm{AlCl}_{4}^{-}+\mathrm{AlOCl}_{3}^{2-} \\
& \mathrm{UO}^{4+}+\mathrm{Al}_{2} \mathrm{Cl}_{7}^{2-} \rightleftharpoons \mathrm{U}^{6+}+\mathrm{AlCl}_{4}{ }^{-}+\mathrm{AlOCl}_{3}^{2-} \\
& \mathrm{U}^{6+}+\mathrm{AlCl}_{4}^{-} \rightleftharpoons \mathrm{U}^{5+}+\mathrm{AlCl}_{3}+1 / 2 \mathrm{Cl}_{2}
\end{aligned}
$$

The electrochemical studies of neptunium in acidic and basic $\mathrm{AlCl}_{3}-1-n$-butylpyridinium chloride melt at $313 \mathrm{~K}$ was studied by Schoehrechts and Gilbert. ${ }^{42}$ In acidic and basic melts, the reduction of $\mathrm{Np}(\mathrm{IV})$ to $\mathrm{Np}$ (III) at glassy carbon electrode was quasi-reversible. In basic melt, $\mathrm{Np}$ (III) and $\mathrm{Np}(\mathrm{IV})$ exists as $\mathrm{NpCl}_{6}{ }^{3-}$ and $\mathrm{NpCl}_{6}{ }^{2-}$ where as in acidic melt it exist in the form of solvated $\mathrm{Np}^{3+}$ and $\mathrm{NpCl}_{x}^{(4-x)-}(3 \geq x \geq 1)$. The study showed that acidic melt act as a poor solvating medium for lanthanides and neptunium.

The redox behavior of actinides in $1^{\text {st }}$ generation haloaluminate melts demonstrate that the electrochemical window of haloaluminate permits the redox conversion of An(III) $\longleftrightarrow$ An(VI) only depending upon the composition of RTIL. 
Reduction of $\mathrm{An}$ (III) to $\mathrm{An}^{0}$ was not feasible due to inadequate cathodic stability of haloaluminates. A similar behavior could be expected for lanthanides also, as the characteristic trivalents are hard to reduce to metallic state than actinides. The studies reported by Schoebrechts et $\mathrm{al}^{43,44}$ also confirms that some trivalent lanthanides ions such as $\mathrm{Sm}^{3+}, \mathrm{Eu}^{3+}, \mathrm{Tm}^{3+}$, and $\mathrm{Yb}^{3+}$ dissolved in acidic $\mathrm{AlCl}_{3}-\mathrm{BuPyCl}$ ionic liquid were reduced only to the corresponding divalent ions. Due to these limitations, RTILs have not gained the popularity in non-aqueous reprocessing earlier. However, with the advent of moisture-stable $2^{\text {nd }}$ generation ionic liquids having an electrochemical window as large $\sim 6 \mathrm{~V}$ and good cathodic stability, in late 1990s, gave a renaissance to RTILs in non-aqueous reprocessing. An excellent review in this regard by Abbot and Mckenzie ${ }^{45}$ deals with the application of RTILs for the electrodeposition of metals, provides an insight into the electrodeposition of technologically important metals using a wide range of RTILs, and addresses the practical and theoretical aspects that need to be considered when choosing ionic liquids as electrolytes.

Nikitenko and co-workers ${ }^{46-48}$ investigated the spectroscopic and electrochemical aspects of U(IV)-hexachloro complexes in $\operatorname{bmim}\left[\mathrm{NTf}_{2}\right],\left[\mathrm{Mebu}_{3} \mathrm{~N}\right]\left[\mathrm{NTf}_{2}\right]\left(\mathrm{Mebu}_{3} \mathrm{~N}=\right.$ tri- $n$-butylmethyl ammonium) hydrophobic ionic liquids. Due to large electrochemical window of RTIL, it was possible to study the oxidation and reduction behaviour, up to the metallic form. The uranium redox values depend strongly on the type on RTIL cation. $\left[\mathrm{UCl}_{4}\right]^{2-}$ in $\left[\mathrm{Mebu}_{3} \mathrm{~N}\right]\left[\mathrm{NTf}_{2}\right]$ can be converted to metallic uranium at $-3.12 \mathrm{~V}\left(\mathrm{vs} . \mathrm{Fc}^{+} / \mathrm{Fc}\right)$ at $333 \mathrm{~K}$. Nikitenko further investigated $^{48}$ the co-ordination behaviour of $\mathrm{Np}(\mathrm{IV})$ and $\mathrm{Pu}(\mathrm{IV})$ in bmimNTf ${ }_{2}$. The $\left[\mathrm{NpCl}_{6}\right]^{2-}$ and $\left[\mathrm{PuCl}_{6}\right]^{2-}$ compounds are electrochemically inert in bmimNTf ${ }_{2}$ at glassy carbon electrode. However, the addition of bmimCl facilitates the quasireversible electrochemical reduction of $\mathrm{Np}(\mathrm{IV}) / \mathrm{Np}$ (III) and $\mathrm{Pu}(\mathrm{IV}) / \mathrm{Pu}(\mathrm{III})$ and oxidation of $\mathrm{Np}(\mathrm{IV})$ and $\mathrm{Pu}(\mathrm{IV})$. These were reported only when $\mathrm{Cl}^{-} / \mathrm{An}(\mathrm{IV})$ ratio exceed six in ionic liquid medium.

Bhatt et $\mathrm{al}^{49-51}$ studied the electrochemistry of some lanthanides, $\mathrm{La}^{3+}, \mathrm{Sm}^{3+}$, and $\mathrm{Eu}^{3+}$ in $\left[\mathrm{R}_{4} \mathrm{X}\right]\left[\mathrm{Tf}_{2} \mathrm{~N}\right]$, where $\mathrm{X}=\mathrm{N}, \mathrm{P}$ and As. The RTIL, $\left[\mathrm{Me}_{4} \mathrm{X}\right]\left[\mathrm{Tf}_{2} \mathrm{~N}\right]$, exhibits extremely large electrochemical window $(\sim 6 \mathrm{~V})$. Based on the observation that $\mathrm{Eu}(\mathrm{III})$ present in this ionic liquid was reduced to $\mathrm{Eu}^{0}$, it was proposed as a potential electrolytic medium for electrodeposition of uranium and plutonium by non-aqueous reprocessing. Furthermore, they also studied ${ }^{50}$ the reduction of $\mathrm{La}^{3+}, \mathrm{Sm}^{3+}$, and $\mathrm{Eu}^{3+}$ to metallic state in the RTIL, $\left[\mathrm{Me}_{3} \mathrm{NBu}\right]\left[\mathrm{Tf}_{2} \mathrm{~N}\right]$, and reported similar results as in the previous case. The voltammetric behavior of $\left[\mathrm{Th}\left(\mathrm{NTf}_{2}\right)_{4}\left(\mathrm{HNTf}_{2}\right)\right] \cdot 2 \mathrm{H}_{2} \mathrm{O}$ was also studied $^{51}$ in $\left[\mathrm{Me}_{3} \mathrm{NBu}\right]\left[\mathrm{NTf}_{2}\right]$. Th(IV) in this ionic liquid was reduced to $\mathrm{Th}(0)$ by a single reduction step. The $E^{0}$ value for the reduction of $\mathrm{Th}(\mathrm{IV})$ to $\mathrm{Th}(0)$ was determined to be $-2.20 \mathrm{~V}$ (vs $\mathrm{Fc}+/ \mathrm{Fc} ;-1.80 \mathrm{~V}$ vs SHE). A comparison of this $E^{0}$ value with those obtained for $\mathrm{Th}(\mathrm{IV})$ reduction in a $\mathrm{LiCl}-\mathrm{KCl}$ eutectic $(677 \mathrm{~K})$ and other non-aqueous solvents indicated that the reduction of Th(IV) was reported ${ }^{51}$ to be much easier in $\left[\mathrm{Me}_{3} \mathrm{NBu}\right]\left[\mathrm{NTf}_{2}\right]$. Due to the presence of moisture in ionic liquid, the reduced product $\mathrm{Th}(0)$ was converted to $\mathrm{ThO}_{2}$.

Electrochemical behavior of $\mathrm{U}(\mathrm{VI})$ in bmimCl was reported by Giridhar et al. ${ }^{52} \mathrm{U}(\mathrm{VI})$ in bmimCl undergoes a single step two-electron transfer reduction to uranium oxide $\left(\mathrm{UO}_{2}\right)$ deposit at a glassy carbon working electrode. Electrochemical reduction was not only governed by the diffusion of U(VI), but also by charge transfer kinetics at the working electrode. The diffusion coefficient of U(VI) in bmimCl increased with increase of temperature from $6.64 \times 10^{-9} \mathrm{~cm}^{2} / \mathrm{s}$ at $343 \mathrm{~K}$ to $1.69 \times 10^{-8}$ $\mathrm{cm}^{2} / \mathrm{s}$ at $373 \mathrm{~K}$ and the energy of activation was reported as 54 $\mathrm{kJ} / \mathrm{mol}$. Thermal analysis of the uranium oxide deposit obtained by the electrolysis of $\mathrm{U}(\mathrm{VI})$ from bmimCl revealed the entrapment of nearly $5 \%$ bmimCl during electrodeposition.

Chen and Hussey ${ }^{27}$ studied the electrochemistry of the most electropositive fission product, ${ }^{137} \mathrm{Cs}^{+}$, at mercury electrode using $\left[\mathrm{Bu}_{3} \mathrm{meN}\right]\left[\mathrm{NTf}_{2}\right]$ by various voltammetric techniques. The reduction of $\mathrm{Cs}^{+}$at mercury electrode was quasi-reversible and a diffusion coefficient of $\sim 10^{-8} \mathrm{~cm}^{2} / \mathrm{s}$ at $303 \mathrm{~K}$ was reported. Bulk deposition/stripping was conducted at mercury film electrode with recovery of $97 \%$ of loaded cesium by the reaction as shown in equation1.

$\mathrm{Cs}^{+}+\mathrm{Hg}+\mathrm{e}^{-} \rightleftharpoons \mathrm{Cs}(\mathrm{Hg})$

\section{Recovery of valuables from waste}

Ionic liquids are also utilized for various other electrochemical applications, for example, recovery of valuable by-products of nuclear fission, nuclear waste treatment etc. The concept of by-product utilization arising from nuclear industry was evolved in 1950's itself. The long-lived radioactive elements such as ${ }^{137} \mathrm{Cs}\left(t_{1 / 2}=30.1 \mathrm{y}\right)$ and ${ }^{90} \mathrm{Sr}\left(t_{1 / 2}=28.5 \mathrm{y}\right)$ in addition to some non-radioactive platinum groups metals are produced, in significant quantities, as by-products of fission..$^{53,54}$ These were regarded as waste a few decades ago and are being termed now as valuables owing to the upsurge in the utilization of these radioisotopes in the area of medicine, food irradiation, and sewage treatment etc in recent years. Applications of RTILs for the recovery of $\mathrm{Cs}^{+}$and $\mathrm{Sr}^{2+}$ were already discussed in aqueous and non-aqueous reprocessing. The next few sections discussing about the recovery of fission platinoids present in spent fuel and nuclear waste.

Platinum group metal (PGM) recovery. Significant quantities of PGMs (palladium, rhodium, and ruthenium), most of them are non-radioactive, are produced as fission products. ${ }^{53}$ Rao and co-workers ${ }^{55-57}$ extensively studied the recovery of palladium and rhodium from aqueous medium by Ex-El process ${ }^{55}$ as well as by non-aqueous routes using ionic liquid as medium. ${ }^{56,57}$ PGMs in bmimCl are speciated as chlorocomplexes, for e.g. rhodium (III) in bmimCl speciated as $\left[\mathrm{RhCl}_{6}\right]^{3-}$ and other chlorocomplexes. Palladium and rhodium chlorocomplexes are reported to be reduced to their metallic form by an irreversible a single step two or three electron transfer, respectively, at the glassy carbon electrode. The mass transfer of rhodium (III) was slower compared to palladium (II) under similar conditions. Electrodeposition of fission palladium from co-existing fission rhodium resulted in a separation factor of $10(\mathrm{Pd} / \mathrm{Rh})$ in the deposit, when the deposition was conducted at palladium deposition potential. However, the separation factor decreased with increase of applied negative potential (towards rhodium deposition potential). The study indicated that co-deposition of fission rhodium $(\sim 10 \%)$ seems to be inevitable during electroseparation of fission palladium from a solution of rhodium(III) and palladium (II) present in bmimCl, perhaps, due to proximity of palladium and rhodium reduction onset potentials.

Wide electrochemical window and ion exchange property of RTIL were exploited ${ }^{55}$ for the recovery of palladium from nitric acid medium. Extraction of palladium by commercial ionic liquids, TOMAC and TOMAN, was studied as a function of various parameters and the palladium complex in organic phase was reported to undergo a single step two-electron reduction process at the working electrode. ${ }^{55}$ Palladium was deposited both from the solutions containing diluent, chloroform, as well as after recovering chloroform by distillation. Controlled potential electrolysis of palladium extracted organic phase results in a deposition of metallic palladium, which was shown to be free from other fission products such as ${ }^{137} \mathrm{Cs},{ }^{90} \mathrm{Sr}$, and ${ }^{154} \mathrm{Eu}$. Therefore this method (Ex-El process) provides two-step decontamination from fission products during extraction and electrodeposition.

Treatment of tissue paper waste and recovery of valuables. Utilization of RTILs for nuclear waste treatment is another 
subject of growing interest. In this context, a new method was reported for the dissolution of tissue paper waste and recovery of valuable contaminants by using RTILs. ${ }^{58}$ Large volumes of ash less filter paper as well as tissue paper waste contaminated with either strategic materials or fission products are generated at fuel cycle facilities. The procedure reported for the recovery of valuables from tissue paper involves the dissolution of waste in bmimCl. The valuable contaminant such as uranium (VI) chloride/nitrate salt present in tissue paper also dissolve in bmimCl along with tissue paper. However, it was recovered by electrodeposition. In this context, the electrochemical behavior of uranium (VI) in a solution of tissue paper-bmimCl at glassy carbon electrode was reported and the diffusion coefficient of $\mathrm{U}(\mathrm{VI})$ was determined. Electrolysis of a solution of uranium (VI) loaded tissue paper in bmimCl results in a deposition of uranium oxide $\left(\mathrm{UO}_{2}\right)$. The study established the possibility of dissolving tissue paper and other cellulose based materials containing soluble uranium (VI) and Pd(II) compounds in bmimCl, and their recovery from the resultant solution. Cellulose pulp was regenerated by adding surplus water after the recovery of valuables and the ionic liquid, bmimCl, was also regenerated.

Radiochemical stability of RTILs. When RTILs are intended for nuclear fuel cycle applications, they are expected to exhibit adequate thermal and radiation stability. In this context Allen et $a l^{59}$ reported the radiation stability (up to $400 \mathrm{kGy}$ ) of 1,3-alkylmethylimidazolium cation (alkyl is either ethyl, butyl, or hexyl) based ionic liquids containing nitrate and chloride anions. The radiation stability are compared with the workhorse of nuclear fuel cycle namely TBP/odourless kerosene $(\mathrm{OK})$ as well as with benzene. The results suggest that the ionic liquids investigated are much more stable than mixtures of TBP and OK under similar irradiation conditions. Nearly $1 \%$ of RTIL was found to be radiolysed with the absorbed dose was $400 \mathrm{kGy}$, while TBP/OK suffered more than $15 \%$ decomposition. Berthon et $\mathrm{al}^{60}$ reported the radiochemical stability (up to $1200 \mathrm{kGy}$ ) of neat hydrophobic RTILs, bmimPF bnd $_{6}$ bmimNTf ${ }_{2}$ irradiated under argon atmosphere and in air. It was found that the density, surface tension, and refractive index of these RTILs unaltered even by an absorbed dose of approximately $600 \mathrm{kGy}$, however, significant darkening of RTILs occurred after irradiation that led to the linear increase of absorbance of light with absorbed dose. This was attributed to the radiolysis of bmim ${ }^{+}$that results in the generation of primary radicals, which upon recombination results in the formation of various polymeric and acidic species.

\section{Issues to be addressed.}

The above literature on the electrochemical applications of RTILs in nuclear fuel cycle highlights the potentials and promises of RTILs for wide variety of electrochemical applications and they utilize some favourable properties of RTILs for a desired application. However, there are several issues need to be tackled for realizing a robust technology using RTIL as medium. The electrochemical applications discussed in the previous sections involved the electrodeposition of metals from RTIL medium. There are several physical and electrochemical properties of RTIL such as viscocity, conductivity, electrochemical window, kinetics of electron transfer etc, which controls the mass transfer at the interphase and the behavior of electrodeposition. Few excellent reviews in this regard by various authors ${ }^{10,45,61}$ address the properties that need to be considered while choosing ionic liquids as electrolytes. Hence, they are not discussed here. However, from the aqueous and nonaqueous reprocessing point of view, there are some issues, which need to be given priority.

As the RTILs comprise entirely of ions, the properties such as the viscosity, density and aqueous solubility are generally higher than the traditional diluents ( $n$-DD) employed in aqueous reprocessing. Viscosity and density of the solvent are important process parameters that dictate the hydrodynamics of the extractant during solvent extraction process. ${ }^{62}$ It is essential that the viscosity of organic phase $(\sim 2 \mathrm{cP})$ is sufficiently low to permit, ready flow of solutions, low power agitators for phase dispersion, and efficient phase separation. Since these values are significantly higher for the RTILs studied as diluents, serious problems such as phase inversion, longer time for disengagement etc are encountered during solvent extraction. ${ }^{63}$ Nevertheless, the encouraging part of RTILs is that there are $10^{18}$ different ways of combining the cations and anions reported in literature for making a RTIL. Due to these mammoth combinations of cation and anions, it might yet be possible to discover a RTIL, which meets all the desirable properties of reprocessing. Another, important study which has not been attempted is the modality of dissolving the spent nuclear fuel in RTIL medium that has large electrochemical window adequate to deposit actinides. In fact, dissolution of spent nuclear fuel in to the high temperature electrolytic medium is head-end of conventional non-aqueous reprocessing. However no such methods are reported so far using RTILs as electrolytic medium and it requires collective efforts of both theoretical and electrochemical understanding for engineering an RTIL that can deliver a paradigm shift in reprocessing technology.

\section{Summary and outlook}

Room temperature ionic liquids have inscribed a beginning in nuclear industry. The results reported so far on the separation of actinides and fission products by aqueous and non-aqueous methods using RTIL as a medium are encouraging. The emerging technologies using RTILs provide industrially adaptable conditions for reprocessing and waste management. While these new results and novel technologies exhibit a great potential, the hurdles associated with the new technology need to be resolved for maturing into a robust technology. This can be manifested by intellectual design RTILs by judicial combination of ions from trillions of ions reported in literature, to meet the desirable results.

\section{References}

(1) P.K. Dey and N.K. Bansal, Nucl. Eng. Design 236, 723 (2006).

(2) J.I. Swanson, PUREX Process Flowsheets, in: Science and Technology of Tributyl phosphate, Vol III, Eds. W.W. Schulz, L.L. Burger, J.D. Navratil, and K.P. Bender, CRC Press Inc. Boca Raton, (1984), p 55.

(3) J. J. Laidler, J. E. Battles, W. E. Miller, J. P. Ackerman, and E. L. Carls, Prog. Nucl. Energy 31, 131 (1997).

(4) C.C. Mcpheeters, R.D. Pierce, and T.P. Mulcahey, Prog. Nucl. Energy 31, 175 (1997).

(5) T. Welton, Chem. Rev. 99, 2071 (1999).

(6) J.D. Holbrey and K.R. Seddon, Clean Products Processes 1, 223 (1999).

(7) M.J. Earle and K.R. Seddon, Pure Appl.Chem. 72, 1391 (2000).

(8) J.S. Wilkes, Green Chem. 4, 73 (2002).

(9) S. Pandey, Anal. Chim. Acta 556, 38 (2006).

(10) D.S. Silvester and R.G. Compton, Z. Phys. Chem. 220, 1247 (2006).

(11) S.A. Forsyth, J.M. Pringle, and D.R. MacFarlane, Aust. J. Chem. 57, 113 (2004).

(12) F. Endres, Chem. Phys. Chem. 3, 144 (2002).

(13) M.C. Buzzeo, R.G. Evans, and R.G. Compton. Chem. Phys. Chem. 5, 1106 (2004).

(14)F. Endres and S.Z. El Abedin, Phys. Chem. Chem. Phys. 8, 2101 (2006). 
(15) P. Walden, Bull. Acad. Imper. Sci. (St. Petersburg), 1800 (1914).

(16) F.H. Hurley and T.P. Wier Jr., J. Electrochem. Soc. 98, 203 (1951).

(17) R.J. Gale, B. Gilbert, and R.A. Osteryoung, Inorg. Chem. 17, 2728 (1978).

(18) J.S. Wilkes and M.J. Zaworotko, J. Chem. Soc. Chem. Commun. 965 (1992)

(19) M.L. Dietz and J.A. Dzielawa, Chem. Commun. 2124 (2001).

(20) J.G. Huddleston, H.D. Willauer, R.P. Swatloski, A.E. Vissser, and R.D. Rogers, Chem. Commun. 1765 (1998).

(21) A.E. Visser, R.P. Swatloski, S.T. Griffin, D.H. Hartman, and R.D. Rogers, Sep. Sci. Technol. 36, 785 (2001).

(22) A.E. Visser, R.P. Swatloski, W.M. Reichert, S.T. Griffin, and R. D. Rogers, Ind. Eng. Chem. Res. 39, 3596 (2000).

(23) S. Dai, Y.H. Ju, and C.E. Barnes, J. Chem. Soc. Dalton Trans. 1201 (1999).

(24) S. Chun, S.V. Dzyuba, and R.A. Bartsch, Anal. Chem. 73, 3737 (2001)

(25) A.E. Visser, R.P. Swatloski, W.M. Reichert, R. Mayton, S. Sheff, A. Wierzbicki, J.H.Davis Jr., and R.D. Rogers, Chem. Commun. 135 (2001).

(26) A. E. Visser and R. D. Rogers, J. Solid State Chem. 171, 109 (2003).

(27) P.Y. Chen and C.L. Hussey, Electrochim. Acta 49, 5125 (2004).

(28) P.Y. Chen and C.L. Hussey, Electrochim. Acta 50, 2533 (2005).

(29) P.Y. Chen, Electrochim. Acta 52, 5484 (2007).

(30) P. Giridhar, K.A. Venkatesan, S. Subramaniam, T.G. Srinivasan, and P.R.V. Rao, Radiochim. Acta 94, 1 (2006).

(31) G. Koch, Reprocessing by quaternary ammonium nitrates: laboratory studies. In Solvent Extraction Chemistry of Metals. Eds. H.A.C. McKay, T.V. Healy, and I.L. Jenkins MacMillan (1966) 247.

(32) P. Giridhar, K.A. Venkatesan, S. Subramaniam, T.G. Srinivasan, and P.R.V. Rao, J. Alloys Comp. 448, 104 (2008).

(33) P. Giridhar, K.A. Venkatesan, T.G. Srinivasan, and P.R.V. Rao, J. Radioanal. Nucl. Chem. 265, 31 (2005).

(34) R. De Waele, L. Heerman, and W. D’Olieslager, J. LessCommon Metals 122, 319 (1986).

(35) V.A. Cocalia, K.E. Gutowski, and R.D. Rogers, Coord. Chem. Rev. 250, 755 (2006).

(36) K. Binnemans, Chem. Rev. 107, 2592 (2007).

(37) R. De Waele, L. Heerman, and W. D'Olieslager, J. Electroanal. Chem. 142, 137 (1982).

(38) L. Heerman, R. De Waele, and W. D'Olieslager, J. Electroanal. Chem. 193, 289 (1985).

(39) P.B. Hitchcock, T.J. Mohammed, K.R. Seddon, J.A. Zora, C.L. Hussey, and E.H. Ward, Inorg. Chim. Acta 113, L25 (1986).

(40)C.J. Anderson, M.R. Deakin, G.R. Choppin, W. D'Olieslager, L. Heerman, and D.J. Pruett, Inorg. Chem. 30, 4013 (1991).

(41) C.J. Anderson, G.R. Choppin, D.J. Pruett, D. Costa, and W.
Smith, Radiochim. Acta. 84, 31 (1999).

(42) J. P. Schoebrechts and B.P Gilbert, Inorg. Chem. 24, 2105 (1985).

(43) J.P. Schoebrechts, B.P. Gilbert, and G. Duyckaerts, J. Electroanal. Chem. 145, 127 (1983).

(44) J.P. Schoebrechts, B.P. Gilbert, and G. Duyckaerts, J. Electroanal. Chem. 145, 139 (1983).

(45) A.P. Abbott and K.J. McKenzie, Phys. Chem. Chem. Phys. 8, 4265 (2006).

(46) S.I. Nikitenko, C. Cannes, C. Le Naour, P. Moisy, and D. Trubert, Inorg. Chem. 44, 9497 (2005).

(47) S.I. Nikitenko, C. Hennig, M.S. Grigoriev, C. Le Naour, C. Cannes, D. Trubert, E. Bosse, C. Berthon, and P. Moisy, Polyhedron 26, 3136 (2007).

(48) S.I. Nikitenko and P. Moisy, Inorg. Chem. 45, 1235 (2006).

(49) A.I. Bhatt, I. May, V.A. Volkovich, M.E. Hetherington, B. Lewin, R.C. Thied, and N. Ertok, J. Chem. Soc. Dalton Trans. 4532 (2002).

(50) A.I. Bhatt, I. May, V.A. Volkovich, D. Collison, M. Helliwell, I.B. Polovov, and R.G. Lewin, Inorg. Chem. 44, 4934 (2005).

(51) A.I. Bhatt, N.W. Duffy, D. Collison, I. May, and R.G. Lewin, Inorg. Chem. 45, 1677 (2006).

(52) P. Giridhar, K.A. Venkatesan, T.G. Srinivasan, and P.R.V. Rao, Electrochim. Acta 52, 3006 (2007).

(53) H.J. Ache, L.H. Baetsle, R.P. Bust, A.F. Nechaev, V.P. Popik, and Y. Ying, Feasibility of separation and utilization of ruthenium, rhodium and palladium from high-level waste, IAEA Technical Report Series 308, IAEA, Vienna, (1989).

(54) H.J. Ache, L.H. Baetsle, R.P. Bust, A.F. Nechaev, V.P. Popik, and Y. Ying, Feasibility of separation and utilisation of cesium and strontium from high level waste, Technical Report Series 356, IAEA, Vienna, (1993).

(55)P. Giridhar, K.A. Venkatesan, T.G. Srinivasan, and P.R.V. Rao, Hydrometallurgy 81, 30 (2006).

(56) M. Jayakumar, K.A. Venkatesan, and T.G. Srinivasan, Electrochim. Acta 53, 2797 (2008).

(57) M. Jayakumar, K.A. Venkatesan, and T.G.Srinivasan, Electrochim. Acta, 52, 7121 (2007).

(58) C. J. Rao, K.A. Venkatesan, K. Nagarajan, T.G. Srinivasan, and P.R.V. Rao, Electrochim. Acta. 53, 1911 (2007).

(59) D. Allen, G. Baston, A.E. Bradley, T. Gorman, A. Haile, I. Hamblett, J.E. Hatter, M.J.F. Healey, B. Hodgson, R. Lewin, K.V. Lovell, B. Newton, W.R. Pitner, D.W. Rooney, D. Sanders, K.R. Seddon, H.E. Sims, and R.C. Thied, Green Chem. 4, 152 (2002)

(60) L. Berthon, S.I. Nikitenko, I. Bisel, C. Berthon, M. Faucon, B. Saucerotte, N. Zorz, and Ph. Moisy, Dalton Trans. 2526 (2006).

(61) L. Cassayre, J. Serp, P. Soucek, R. Malmbeck, J. Rebizant, and J.P. Glatz, Electrochim. Acta 52, 7432 (2007).

(62) G.M. Ritcey and A.W. Ashbrook, Solvent Extraction, Principles and Applications to Process Metallurgy. Part 1\& II. Amsterdam Elsevier, 1979

(63)P. Giridhar, K.A. Venkatesan, T.G. Srinivasan, and P.R.V. Rao, J. Nucl. Radiochem. Sci. 5, 17 (2004). 